\title{
Nutritional characteristics and bioactive compounds of different ovo-vegetarian diets supplemented with spirulina
}

\author{
Galal A. Ghazal \\ Department of Food Technology, Faculty of Agriculture, Benha University, 13736 Moshtohor, Qaliuobia, Egypt. \\ Corresponding author: galal.ibrahim@fagr.bu.edu.eg
}

\begin{abstract}
Innovative research in human nutrition during the past few years recommending the contribution of functional vegetarian diets to improve human health and to minimize risk diseases. In present study, three innovative ready-to-use (RTU) and ready-to-eat (RTE) chickpea-based ovo-vegetarian diets (OVDs) incorporating different vegetables (pea, taro, and broccoli) at $15 \%$ were prepared. These formulated OVDs with $34 \%$ chickpea were either supplemented with $1 \%$ spirulina as food supplement or formulated without spirulina. Herein, the nutritional and bioactive compounds of those OVDs could be investigated. Chemical composition, minerals content, bioactive compounds and antioxidant activity as well as amino acids content of OVDs before and after cooking were determined. RTE OVDs with or without spirulina were organoleptically tested after frying cooking. Results of composite analysis were 62.46 to $68.54,17.52$ to $20.57,5.54$ to $6.19,6.97$ to $8.92,5.09$ to 6.65 and 61.49 to $63.84 \%$ for moisture, crude protein, lipids, ash, fiber and available carbohydrate contents in RTU OVDs, respectively. Significant differences $(p<0.05)$ were found in chemical composition in RTU and RTE as well as caloric value of OVDs. RTU CVDs exhibit appropriate content of ascorbic acid, total phenolic compounds (TPC) flavonoids and flavonols which basically depends on their ingredients and possess a valuable antioxidant activity. However, frying process dramatically reduced the ascorbic acid, flavonoids and flavonols contents. Addition of spirulina had increased the minerals, phytochemicals and amino acids contents in OVDs. High organoleptic acceptability of RTE OVDs was noticed to confirm the consumer attractiveness. In conclusion, the possibility to produce healthy RTU and RTE OVDs incorporated with common consumed vegetables supplemented with spirulina could provide a promising approach for improving the human health and dietary pattern practices.
\end{abstract}

Keywords: Spirulina, bioactive compounds, amino acids, cooking, antioxidant activity, ovo-vegetarian diets, health benefits.

\section{Introduction}

Recently, there has been a renewed interest in vegetarian diets and healthy eating. The vegetarian diets are often diverse formulated in composition and shape, comprising a wide range of dietary compnents for numerous and individual dietary requirments. Practically, adopting a vegetarian dietary pattern is traditionally interpreted to mean an absence of meat (Craig and Mangels, 2009; Fraser, 2009). Basically, vegetarians are distinguished by high consumption of fruit, vegetables, legumes, nuts, grains and soy proteinfood components, and each of these may independently be associated with positive health impacts (Messina, 1999; Hunt, 2003; Craig and Mangels, 2009; McEvoy et al., 2012). Particularly, vegetarian diete were classified into (i) lacto-ovo-vegetarians (includes dairy and eggs), (ii) lacto-vegetarians (includes dairy), (iii) ovo-vegetarians (includes eggs), and (iv) vegan which have further restrictions imposed and exclude all animal origin foods. Additionally, the meat substituting industry was highly encouraged to reduce the meat consumption and thereby reduce the risk of related disease. Obviously, substituting the meat consumption by alternative protein rich products made from plant proteins, so-called Novel Protein Foods, would be an attractive choice (Jongen and Meerdink, 2001). The vegetarian diet could significantly reduce people's risk of heart disease as suggested by Oxford University. The vegetarians have up to $32 \%$ less risk of developing heart disease than non-vegetarians (Sacks and Kass, 1988; Fraser, 2009; Jakszyn et al., 2011). Actually, it could encourage the processed meat consumers to change their nutritional style and prevent themselves from $42 \%$ higher risk of heart disease, a $19 \%$ higher risk of type 2 diabetes and bladder cancer as previously mentioned (Micha et al., 2010; McEvoy et al., 2012). Promising sources for new products and applications are Microalgae, a biological resource that enhance the nutritional value of food products, by enrich the polyunsaturated fatty acids, pigments, sterols, vitamins, and other biologically active compounds (Pulz and Gross, 2004). Spirulina had been used as a nutrient-dense food many countries. Indeed, nowadays 
microalgae are mainly marketed as food supplements with growing market for food products either as nutritious supplement, or as a source of natural food colourant as well as unique and attractive tastes (Richmond, 2008). Spirulina had been used in the traditional food products, like biscuits (Gouveia et al., 2008), pasta (Fradique et al., 2010), mayonnaises/salad dressings (Raymundo et al., 2005) and puddings/gelled desserts (Batista et al., 2011) have been previously studied as vehicles to microalgae addition.

Expressively, vegetarians tend to have lower overall cancer rates, lower body mass index (BMI), adjustable blood pressure by eating diets lower in saturated fats, have higher levels of dietary fiber, magnesium, iron and potassium, vitamins $\mathrm{E}$ and folate, carotenoids, flavonoids and other phytochemicals (Sacks and Kass, 1988; Kumaran and Joel Karunakaran, 2007; Al-Duais et al., 2009; Micha et al., 2010; McEvoy et al., 2012). Practically, vegetables are commonly eaten as fresh or cooked for improving its sensory properties. The phytochemicals have been described to possess antimutagenic or even anticarcinogenic activity (AlDuais et al., 2009; Gorinstein et al., 2009). The Egyptian cuisine is notably conducive to ready-to-use and ready-to-eat vegetarian diets, as it rely heavily on vegetable dishes. However, several commonly consumed vegetables such as cauliflower, green pea, green bean, spinach and green zucchini were favorable for Egyptian consumers over the years ago. There are many studies reviews the health benefits of mentioned vegetables considering their phytochemicals content and potential antioxidant, anticarcinogenic, antimicrobial activities (Nilsson et al., 2004; Krumbein et al., 2006; Mitchell et al., 2009; Świątecka et al., 2010; Tang, 2010; Jacobo-Valenzuela et al., 2011; Doria et al., 2012; Limón et al., 2014). Indeed, carefully planned vegetarian and vegan diets can provide adequate nutrients for optimum health (Craig and Mangels, 2009). Clearly, evidence suggests that infants and children can be successfully reared on vegan and vegetarian diets (Mangels and Messina, 2001; Messina and Mangels, 2001).

Vegetarian and vegan diets need to ensure a balance of nutrients from a wide variety of foods, especially for vulnerable groups. Improving dietary habits is a societal, not just an individual problem. Thus it demands a population-based, multisectoral, multidisciplinary, and culturally relevant approach. Accordingly, the main objectives of this study were to investigate the possibility to prepare innovative VDs from different vegetables incorporated with chickpea as protein source supplemented with spirulina. Studying the effect of frying cooking method as well could be investigated. To achieve this purpose, six ovovegetarian diets have been developed by incorporating 3 different vegetables with chickpea and spirulina as well as some other edible ingredients. Proximate chemical composition, minerals, bioactive compounds and their antioxidant activity, amino acids as well as the organoleptic properties for prepared diets were carried out.

\section{Materials and methods}

\subsection{Ingredients:}

Three different vegetables namely, pea (Pisum sativum L.), taro corms (Colocasia esculenta L.), and broccoli (Brassica oleracea L.) were obtained in fresh status from the central local vegetable market at El-Obour City, Egypt. Dry edible chickpea (Cicer arietinum L.), sweet potato (Ipomoea batatas L.), wheat flour, carrot (Daucus carota L.), green leafy vegetables mix [fresh coriander (Coriandrum sativum L.), dill (Anethum graveolens L.), parsley (Petroselinum crispum L.)], red pepper (Capsicum annuum L.), onion (Allium cepa L.), garlic (Allium sativum L.) eggs and edible salt were obtained from the local supermarket, Egypt. In addition, traditional spices were brought from Ragab El-Attar's local spices supermarket, Egypt then was formulated according to (Barakat and Rohn, 2014). Spirulina was obtained from Aquaculture Research Center at Arab Academy for Science, Technology \& Maritime Transport, Arab League, Egypt.

\subsection{Ingredients preparation:}

All mentioned vegetables were washed, sorted and prepared as follow: green pea was peeled; taro corms were peeled manually by sharp knife then chopped into $1 \times 1 \times 1 \mathrm{~cm}$ cubes. The green leaves of fresh broccoli plants were removed; the florets were cut into $1.5-2 \mathrm{~cm}$ parts. All prepared vegetables were washed and blanched for appropriate time (3, 7 and $3 \mathrm{~min}$, respectively) using live steam blancher then cooled down and kept until use under freezing conditions. Unpeeled chickpeas were washed and soaked in water for $12 \mathrm{~h}$. Then, excessive water was drained and chickpeas were peeled manually and ground for $3 \mathrm{~min}$ using a conventional kitchen machine. Sweet potato and carrots were peeled, washed, chopped in $1 \mathrm{~cm}$ slices, and blanched using live steam blancher for 6 and 4 min, respectively. Subsequently, the blanched materials were immediately cooled down and homogenized to a homogeneous puree. Sweet red pepper was washed and chopped in small cubes after removing the intial seeds. Further ingredients such as fresh onion and garlic were peeled, washed and then chopped immediately before preparing the vegetarian diets. To prepare the green leafy vegetables mix, fresh coriander, dill and parsley were washed, ripped then mixed as $(2: 1: 1)$ respectively. The dried spices mixed then used immediately. 


\subsection{Different innovative ready-to-use OVDs preparation:}

Six ovo-vegetarian diet formulas were prepared from the previously prepared ingredients according to recipes in Table 1. Tow kilograms from each formula were prepared using a kitchen machine. Each ready-touse ovo-vegetarian formula was filled in 2 polyethylene bags as $0.3 \mathrm{~kg}$ for chemical analysis of fresh diet and $1.7 \mathrm{~kg}$ for stir-frying process and chemical analysis of fried diets. The big diets bags were kept for homogeneity of all ingredients for 12-18 hr under cooling conditions before frying, while small diet bags were subjected immediately for analysis. The whole experiment and analysis were done in triplicates.

\subsection{Different innovative ready-to-eat OVDs preparation:}

Ready-to-eat OVDs were left at room temperature for 5 min then mixed with $0.1 \%$ sodium bicarbonate amount immediately before frying. The vegetarian diet mixture was shaped using a frame and wide knife which were designed especially for this purpose. Appropriate amounts of each prepared diet mixture was put into the frame, and then cut with the knife as symmetrical bars as $(10 \times 0.8 \times 0.6 \mathrm{~cm}: \mathrm{L} \times \mathrm{W} \times \mathrm{T})$ prior to frying. The vegetarian bars were fried at $180-$ $190^{\circ} \mathrm{C}$ for 3-5 $\mathrm{min}$ in preheated sun flower oil. The OVDs were served immediately after frying for the panelists to evaluate its organoleptic characteristics. However, appropriate samples have been taken off for chemical and phytochemicals analysis.

\subsection{Proximate chemical composition and minerals content:}

Ready-to-use and ready-to-eat OVDs were subjected to chemical analysis (moisture, crude protein, crude lipids, ash and crude fibre contents according to methods of A.O.A.C. (2000). However, the avilable carbohyrates content was determined by defference according to Merrill and Watt (1973). The minerals content including sodium and potassium were determined in both prepared fresh and fried vegetarian diets using flame photometry while calcium, magnesium, iron, copper, manganese and zinc contents were determined by atomic absorption spectroscopy according to A.O.A.C. (2000). A standard colorimetric method was employed for phosphorus as mentioned by Borah et al. (2009).

\subsection{Ascorbic acid determination:}

The ascorbic acid content in various OVDs either ready-to-use and ready-to-eat applying the 2,6dichlorophenol-indophenol titrimetric method was determined according to A.O.A.C. (2000). Vitamin C content is expressed as mg $100 \mathrm{~g}^{-1} \mathrm{fw}$. A pure ascorbic acid (Sigma) was used to prepare a standard solution as $\left(1 \mathrm{mg} \mathrm{ml}^{-1}\right)$.

2.7. Total phenolic content (TPC) determination: One $\mathrm{g}$ of dried ready-to-use and ready-to-eat OVDs was mixed with $25 \mathrm{ml}$ of $70 \%$ methanol (v/v). The mixes were shaken vigorously in a dark bottle for 100 $\mathrm{min}$ at $100 \mathrm{rpm}$. After centrifugation at 3,225 $\mathrm{xg}$ for 10 $\mathrm{min}$, the supernatant was collected and the residue was re-extracted twice with $15 \mathrm{ml} \mathrm{70 \%} \mathrm{methanol} \mathrm{for} \mathrm{total}$ phenolic content and antioxidant activity determination. To avoid oxidation, all extracts were stored in the dark at $-20^{\circ} \mathrm{C}$ and analyses were performed within $48 \mathrm{~h}$. The TPC of ready-to-use OVDs as well as ready-to-eat OVDs was determined according to Folin-Ciocalteu spectrophotometric method (Lu et al., 2007). The measurements were compared to a standard curve of prepared gallic acid (GA) solution, and the total phenolic content was expressed as milligrams of gallic acid equivalents (GAE) per gram of dried sample (mg of GAE $\mathrm{g}^{-1} \mathrm{dw}$ ).

\subsection{Determination of antioxidant activity:}

The radical scavenging activity using DPPH reagent (1,1-Diphenyl-2-picrylhydrazyl) for ready-to-use and ready-to-eat OVD extracts have been carried out using modified method by Lu et al. (2007). Each extract from fresh and fried diets $(0.1 \mathrm{ml})$ was added to $2.9 \mathrm{ml}$ of $6 \times 10^{-5}$ mol methanolic solution of DPPH. The absorbance at $517 \mathrm{~nm}$ was measured after the solution had been allowed to stand in the dark for $60 \mathrm{~min}$. The Trolox calibration curve was plotted as a function of the percentage of DPPH radical scavenging activity. The final results were expressed as micromoles of Trolox equivalents (TE) per gram $\left(\mu \mathrm{mol} \mathrm{TE} \mathrm{g}{ }^{-1} \mathrm{dw}\right)$.

\subsection{Analysis of phytochemicals}

\subsubsection{Total carotenoids determination}

According to Yuan et al. (2009); $5 \mathrm{~g}$ of each freezedried OVDs were extracted with a mixture of acetone and petroleum ether $(1: 1, \mathrm{v} / \mathrm{v})$ repeatedly using the mortar and pestle until a colorless residue was obtained. The upper phase was collected and combined with crude extracts after washed for several times with water. The extracts were made up to a known volume with petroleum ether. Total carotenoids content was determined by recording the absorbance at $451 \mathrm{~nm}$ with a spectrophotometer. Total carotenoids were estimated as $\mathrm{mg} \mathrm{g}^{-1} \mathrm{dw}$.

\subsubsection{Flavonoids and flavonols determination:}

The total flavonoids content of ready-to-use and readyto-eat OVDs were determined according to the method of Mohdaly et al. (2012). A $0.5 \mathrm{ml}$ aliquot of $2 \% \mathrm{AlCl}_{3}$ ethanolic solution was added to $0.5 \mathrm{ml}$ of the extracts and mixed well. After keeping for $1 \mathrm{~h}$ at room 
temperature, the absorbance at $420 \mathrm{~nm}$ was measured. A yellow color indicates the presence of flavonoids. The total flavonoids content were expressed as $\mathrm{mg}$ quercetin equivalent (QE) per $100 \mathrm{~g} \mathrm{dw}$. The total flavonols content were determined according to Kumaran and Karunakaran (2007). A $0.6 \mathrm{ml}$ aliquot of
$2 \% \mathrm{AlCl}_{3}$ ethanolic solution was added to $0.6 \mathrm{ml}$ of each extract and $0.8 \mathrm{ml}$ of a $5 \%$ aqueous sodium acetate solution were added. After mixing and keeping for 2.5 $\mathrm{h}$ at room temperature, the absorbance at $440 \mathrm{~nm}$ was measured. Total flavonols content were expressed as mg quercetin equivalent (QE) per $100 \mathrm{~g} \mathrm{dw}$.

Table 1. Innovative chickpea-based ready-to-use vegan diet recipes

\begin{tabular}{lcccccc}
\hline \multirow{2}{*}{ Ingredients $^{\text {a }}$} & \multicolumn{7}{c}{ Ready-to-use OVD recipes (\%) } \\
\cline { 2 - 7 } & $\mathrm{CP}-\mathrm{S}$ & $\mathrm{CP}+\mathrm{S}$ & $\mathrm{CT}-\mathrm{S}$ & $\mathrm{CT}+\mathrm{S}$ & $\mathrm{CB}-\mathrm{S}$ & $\mathrm{CB}+\mathrm{S}$ \\
\hline Peeled soaked chickpea & 34 & 34 & 34 & 34 & 34 & 34 \\
Green pea & 16 & 15 & - & - & - & - \\
Taro & - & - & 16 & 15 & - & - \\
Broccoli & - & - & - & - & 16 & 15 \\
Spirulina & - & 1 & - & 1 & - & 1 \\
Fixed ingredients $^{\mathrm{b}}$ & 50 & 50 & 50 & 50 & 50 & 50 \\
\hline
\end{tabular}

${ }^{a}:$ All mentioned ingredients were obtained on fresh status (see materials),

${ }^{\mathrm{b}}$ : Fixed ingredients were mixed as [18\% blanched sweet potato, $20 \%$ wheat flour, $12 \%$ blanched carrot puree, $12 \%$ green leafy vegetables mix (coriander: dill: parsley; $2: 1: 1$ ), $12 \%$ red pepper paste, 10 white eggs, $10 \%$ fresh onion, $2.5 \%$ salt, $1.5 \%$ fresh garlic and $2 \%$ dried spices.

\subsection{Amino acids determination:}

The amino acids profile was carried out after hydrolysis by $6.0 \mathrm{~N} \mathrm{HCl}$ for $24 \mathrm{~h}$ at $110^{\circ} \mathrm{C}$ in evacuated ampoules. Quantitative determination of amino acids were carried out by Biochrome 30 instruction manual (Analyzer used), 2005. EZ chrome manual (software for data collection and processing), 2004 according to A.O.A.C. (A.O.A.C., 2012).

\subsection{Organoleptic evaluation:}

Organoleptic evaluation of the ready-to-eat OVDs immediately after preparation of the six OVDs incorporating different vegetables and spirulina was carried out. Fifteen panelists of the staff members and students from the Food Technology Department, Faculty of Agriculture, Benha University, in the age range of 20 to 57 years were asked to evaluate the fried OVD bars towards appearance, color, taste, odor, texture, oiliness, and overall acceptability. A 7-point hedonic scale ( 7 being like extremely, 4 like accepted and 1 dislike extremely) was used to select the best recipe for a wide scale production. Results were subjected to analysis of variance and average of the mean values of the aforementioned attributes and their standard error were calculated according to Wilson et al. (1998).

\subsection{Statistical analysis:}

The statistical analysis was carried out using SPSS program with multi-function utility regarding to the experimental design under significance level of 0.05 for the whole results. Multiple comparisons applying LSD were carried out according to Steel et al. (1997). However, the descriptive values of data were represented as means \pm standard deviation (SD).

\section{Results and discussion}

\subsection{Proximate chemical composition of innovative ready-to-use and ready-to-eat OVDs:}

The chemical composition of prepared OVDs and their caloric value were significantly differed between RTU and RTE regardless spirulina supplement as illustrated in Table 2. Practically, obtained results of proximate chemical composition concluded that prepared diets are considered as valuable source of crude protein, lipid, fiber and avilable carbohydrates both RTU and RTE OVDs which may have appropriate health benefits (Messina, 1991; Chiplonkar et al., 1999; Krumbein et al., 2006; Fraser, 2009; TurnerMcGrievy, 2010; McEvoy et al., 2012). The moisture content had peaked in RTU $\mathrm{CT}+\mathrm{S}$ and $\mathrm{RTE} \mathrm{CB}+\mathrm{S}$ to be 68.54 and $56.00 \%$, respectively. Although, it had bottomed in $\mathrm{RTU} \mathrm{CP}+\mathrm{S}$ and $\mathrm{RTE} \mathrm{CT}+\mathrm{S}$ reaching to 62.46 and $52.77 \%$, respectively. However, a slight difference between selected vegetables with or without spirulina and vice versa after cooking. That's meaning, around $10 \%$ reduction in the moisture content of fried OVD diets was recorded according to their means values. Spirulina incorporation into different vegetables directed to increasing the crude protein, lipids content and ash content in $\mathrm{CP}+\mathrm{S}, \mathrm{CB}+\mathrm{S}$ and $\mathrm{CT}+\mathrm{S}$, respectively. Thus, these formulas were the highest mentioning parameters as presentable in Table 2. Moreover, the frying process was negatively affected on crude protein and fiber as well as available carbohydrate contents for some formulas. Conversely, 
it was clearly increased the lipids, ash and caloric values for OVDs as shown by Barakat (2013). Frying cooking increased the lipid content in all diets by double times when compared to fresh diets. All formulated diets seems to have adequate fiber content which was not significantly different in the most of prepared diets. According to Dietary Reference Intakes (2002), the formulated OVDs, $100 \mathrm{~g} \mathrm{dw}$ could provide at least $40-50 \%$ of the RDA for adults and at least $25-35 \%$ of the RDA for pregnant and lactating women daily. In context, Adequate Intake (AI) of dietary fiber could be compensated. Moreover, RDA of carbohydrates is $130 \mathrm{~g} \mathrm{~d}^{-1}$ for age ranging from 970 years of both genders, which increased to $210 \mathrm{~g} \mathrm{~d}^{-1}$ for females in pregnancy and lactation. Consuming about $100 \mathrm{~g} \mathrm{dw}$ OVD could provide at least $25-50 \%$ of the RDA for adults (about 90\% absorbance efficiency). Accordingly as shown, $100 \mathrm{~g}$ of ready-toeat OVDs fw could provide about 187-198 kcal which is cover the requirements of adult person $(70 \mathrm{~kg})$ for about 2.5 - 4 h (DRI, 2002; Gebhardt and Thomas, 2002). These results are in agreement with (Barakat, 2013; Barakat, 2014; Barakat and Rohn, 2014).

\subsection{Minerals content of innovative ready-to-use and ready-to-eat OVDs}

The minerals content (sodium, potassium, calcium, phosphorus, magnesium, iron, copper, manganese and zinc) in (mg $100 \mathrm{~g}^{-1} \mathrm{dw}$ ) of ready-to-use and ready-toeat OVDs are given in Table 3. Generally, minerals content was changed after frying with different reduction rates. Significant difference $(p<0.05)$ was establish between both RTU and RTE OVDs among all minerals. CB-S showed higher sodium content while the lowest content was recorded in $\mathrm{Cp}-\mathrm{S}$. After frying, the sodium content was ranged from $1698.5 \mathrm{mg}$ $100 \mathrm{~g}^{-1} \mathrm{dw}$ in CP-S to $1990.67 \mathrm{mg}^{100 \mathrm{~g}^{-1} \mathrm{dw} \text { in CB-S. }}$ Potassium content in formulated OVDs with different vegetables was ranged from a low of $1410.2 \mathrm{mg} 100 \mathrm{~g}^{-}$ ${ }^{1} \mathrm{dw}$ in CP-S to a high of $1970.37 \mathrm{mg}^{100 \mathrm{~g}^{-1} \mathrm{dw} \text { in CB- }}$ $\mathrm{S}$. The CB-S showed the highest calcium content in both RTU and $\mathrm{CB}+\mathrm{S}$ for RTE, while the lowest calcium content was recorded in both fresh and fried CP-S. The formulated CB+S RTU and CP-S RTE having higher phosphorus content than other formulated vegetables, while the lowest phosphorus content had been recorded in both fresh and fried CP$\mathrm{S}$ and CT-S. High magnesium content was found in fresh $\mathrm{CP}-\mathrm{S}$ and fried $\mathrm{CT}-\mathrm{S}$ followed by $\mathrm{CB}+\mathrm{S}$ diets while iron content in different formulated diets is given in the same table, which was ranged from 287.9 $\mathrm{mg} 100 \mathrm{~g}^{-1} \mathrm{dw}$ in CT-S to $676.23 \mathrm{mg} 100 \mathrm{~g}^{-1} \mathrm{dw}$ in

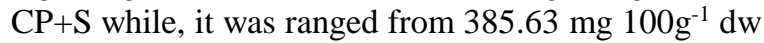

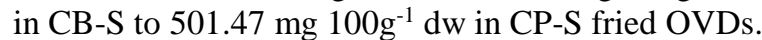
These results were in agreement with (Lightowler and
Davies, 2000; Borah et al., 2009; Barakat, 2013; Barakat, 2014). Our presented results of minerals content may compatible with vegetables and legumes minerals content which were reviewd by Gebhardt and Thomas (2002). For human requirments, the presented minerals content in $100 \mathrm{~g} \mathrm{dw}$ of prepared OVDs could provide avaluable content of ADI and RDA. As mentioned in Dietary Reference Intakes (2002), the presented OVDs seem to rich in some minerals content and supplementing with spirulina slightly increased the minerals but sufficient supplement level may further needed.

\subsection{Ascorbic acid, phytochemicals components and their antioxidant activity of innovative ready-to-use and ready-to-eat OVDs}

Recently, research has confirmed a strong relationship between the amount of available biologically active compounds in vegetables and their antioxidant properties (Gertz et al., 2000; Ismail et al., 2004; Zhang and Hamauzu, 2004; Sikora et al., 2008; Volden et al., 2008; Verkerk et al., 2009; Lamy et al., 2011; Deng et al., 2013; Houghton et al., 2013). Data in Table 4 displays some phytochemicals content of various innovative RTU and RTE OVDs. All fresh diets demonstrated appropriate content of vitamin $\mathrm{C}$ which basically depends on the initial ingredients especially with Spirulina addition. However, the average levels of vitamin $\mathrm{C}$ were affectedly and significantly decreased in RTE OVDs which were influenced by frying cooking (Francisco et al., 2010). Moreover, TPC, flavonoid, flavonols and antioxidant activity of both RTU and RTE-OVDs are also obtainable in the same table. Similarity, the TPC, antioxidant activity, flavonoids and flavonols of fresh prepared OVDs were higher than RTE regardless the vegetable kind. The TPC was a ranged from $52.11 \mathrm{mg}$ $\mathrm{GAE} \mathrm{g}^{-1}$ for RTE CB-S to $81.70 \mathrm{mg} \mathrm{GAE} \mathrm{g}^{-1}$ for RTU $\mathrm{CT}+\mathrm{S}$ (Turkmen et al., 2005; Barakat, 2013). The antioxidant activity was recorded the highest value in RTU CP+S to be $70.42 \mu \mathrm{mol} \mathrm{TE} \mathrm{g}^{-1}$. However, the lowest rate was attained 
Table 2. Chemical composition of innovative read-to-use and read-to-eat chickpea-based ovo-vegetarian diets incorporating different vegetables and supplemented with Spirulina.

\begin{tabular}{|c|c|c|c|c|c|c|c|c|c|c|c|c|c|c|}
\hline \multirow{3}{*}{ Recipes $^{\ddagger}$} & \multicolumn{12}{|c|}{ Chemical composition (\%) } & \multirow{2}{*}{\multicolumn{2}{|c|}{$\begin{array}{l}\text { Caloric value } \\
\mathrm{kcal} / 100 \mathrm{~g}^{\mathrm{fw}}\end{array}$}} \\
\hline & \multicolumn{2}{|c|}{ Moisture content } & \multicolumn{2}{|c|}{ Crude protein ${ }^{\mathrm{dw}}$} & \multicolumn{2}{|c|}{ Lipids ${ }^{d w}$} & \multicolumn{2}{|c|}{$\operatorname{Ash}^{\mathrm{dw}}$} & \multicolumn{2}{|c|}{ Crude fiber ${ }^{\mathrm{dw}}$} & \multicolumn{2}{|c|}{$\begin{array}{c}\text { Available } \\
\text { carbohydrates } \mathrm{dw}\end{array}$} & & \\
\hline & RTU & RTE & RTU & RTE & RTU & RTE & RTU & RTE & RTU & RTE & RTU & RTE & RTU & RTE \\
\hline $\mathrm{CP}-\mathrm{S}$ & $\begin{array}{c}64.03 \\
\pm 0.42^{\mathrm{aB}}\end{array}$ & $\begin{array}{c}54.53 \\
\pm 0.38^{\mathrm{aA}}\end{array}$ & $\begin{array}{c}19.93 \\
\pm 2.8^{\mathrm{bB}}\end{array}$ & $\begin{array}{c}17.09 \\
\pm 0.67^{\mathrm{bA}}\end{array}$ & $\begin{array}{c}5.56 \\
\pm 1.15^{\mathrm{aA}}\end{array}$ & $\begin{array}{c}6.46 \\
\pm 0.28^{\mathrm{aB}}\end{array}$ & $\begin{array}{c}6.97 \\
\pm 0.01^{\mathrm{bA}}\end{array}$ & $\begin{array}{c}6.36 \\
\pm 0.02^{\mathrm{aB}}\end{array}$ & $\begin{array}{c}5.85 \\
\pm 0.28^{\mathrm{bB}}\end{array}$ & $\begin{array}{c}4.33 \\
\pm 0.04^{\mathrm{cA}}\end{array}$ & $\begin{array}{r}61.69 \\
\pm 1.8^{\mathrm{aB}}\end{array}$ & $\begin{array}{c}65.76 \\
\pm 0.59^{\mathrm{bA}}\end{array}$ & $\begin{array}{c}132.67 \\
\pm 2.14^{\mathrm{bA}}\end{array}$ & $\begin{array}{r}191.47 \\
\pm 2.73^{\mathrm{aB}}\end{array}$ \\
\hline $\mathrm{CP}+\mathrm{S}$ & $\begin{array}{c}62.46 \\
\pm 1.66^{\mathrm{aB}}\end{array}$ & $\begin{array}{c}55.76 \\
\pm 0.22^{\mathrm{aA}}\end{array}$ & $\begin{array}{c}20.57 \\
\pm 1.37^{\mathrm{bB}}\end{array}$ & $\begin{array}{c}19.17 \\
\pm 2.01^{\mathrm{bA}}\end{array}$ & $\begin{array}{c}5.65 \\
\pm 0.06^{\mathrm{aA}}\end{array}$ & $\begin{array}{c}6.37 \\
\pm 0.36^{\mathrm{aB}}\end{array}$ & $\begin{array}{c}7.17 \\
\pm 0.03^{\mathrm{eA}}\end{array}$ & $\begin{array}{c}6.61 \\
\pm 0.07^{\mathrm{aB}}\end{array}$ & $\begin{array}{c}5.12 \\
\pm 0.44^{\mathrm{aB}}\end{array}$ & $\begin{array}{c}3.07 \\
\pm 0.02^{\mathrm{aA}}\end{array}$ & $\begin{array}{c}61.49 \\
\pm 0.76^{\mathrm{aB}}\end{array}$ & $\begin{array}{c}64.78 \\
\pm 2.38^{\mathrm{abA}}\end{array}$ & $\begin{array}{c}139.51 \\
\pm 7.21^{\mathrm{bA}}\end{array}$ & $\begin{array}{r}188.57 \\
\pm 2.63^{\mathrm{aB}}\end{array}$ \\
\hline CT-S & $\begin{array}{c}63.81 \\
\pm 0.26^{\mathrm{aB}}\end{array}$ & $\begin{array}{c}53.6 \\
\pm 0.74^{\mathrm{aA}}\end{array}$ & $\begin{array}{r}17.52 \\
\pm 2.1^{\mathrm{aB}}\end{array}$ & $\begin{array}{c}16.96 \\
\pm 3.28^{\mathrm{abA}}\end{array}$ & $\begin{array}{c}5.47 \\
\pm 0.02^{\mathrm{aA}}\end{array}$ & $\begin{array}{c}6.92 \\
\pm 0.35^{\mathrm{bB}}\end{array}$ & $\begin{array}{c}7.05 \\
\pm 0.02^{\mathrm{cA}}\end{array}$ & $\begin{array}{c}6.29 \\
\pm 0.04^{\mathrm{aB}}\end{array}$ & $\begin{array}{c}6.12 \\
\pm 0.22^{\mathrm{cB}}\end{array}$ & $\begin{array}{c}3.75 \\
\pm 0.06^{\mathrm{bA}}\end{array}$ & $\begin{array}{c}63.84 \\
\pm 2.28^{\mathrm{bB}}\end{array}$ & $\begin{array}{c}66.08 \\
\pm 2.69^{\mathrm{bA}}\end{array}$ & $\begin{array}{c}132.70 \\
\pm 0.81^{\mathrm{bA}}\end{array}$ & $\begin{array}{r}198.24 \\
\pm 3.38^{\mathrm{aB}}\end{array}$ \\
\hline $\mathrm{CT}+\mathrm{S}$ & $\begin{array}{c}68.54 \\
\pm 9.03^{\mathrm{bB}}\end{array}$ & $\begin{array}{c}52.77 \\
\pm 0.45^{\mathrm{aA}}\end{array}$ & $\begin{array}{c}18.60 \\
\pm 2.1^{\mathrm{abB}}\end{array}$ & $\begin{array}{c}14.15 \\
\pm 0.34^{\mathrm{aA}}\end{array}$ & $\begin{array}{c}5.54 \\
\pm 0.04^{\mathrm{aA}}\end{array}$ & $\begin{array}{c}6.07 \\
\pm 0.49^{\mathrm{aB}}\end{array}$ & $\begin{array}{c}8.92 \\
\pm 0.02^{\mathrm{dA}}\end{array}$ & $\begin{array}{c}6.53 \\
\pm 0.01^{\mathrm{cB}}\end{array}$ & $\begin{array}{c}6.65 \\
\pm 0.29^{\mathrm{dB}}\end{array}$ & $\begin{array}{c}3.34 \\
\pm 0.03^{\mathrm{aA}}\end{array}$ & $\begin{array}{c}60.29 \\
\pm 3.33^{\mathrm{aA}}\end{array}$ & $\begin{array}{c}69.91 \\
\pm 1.07^{\mathrm{dB}}\end{array}$ & $\begin{array}{c}113.26 \\
\pm 35.26^{\mathrm{aA}}\end{array}$ & $\begin{array}{c}196.88 \\
\pm 4.28^{\mathrm{aB}}\end{array}$ \\
\hline CB-S & $\begin{array}{c}65.63 \\
\pm 0.37^{\mathrm{abB}}\end{array}$ & $\begin{array}{c}53.04 \\
\pm 0.26^{\mathrm{aA}}\end{array}$ & $\begin{array}{c}17.79 \\
\pm 0.98^{\mathrm{aB}}\end{array}$ & $\begin{array}{c}16.06 \\
\pm 1.04^{\mathrm{aA}}\end{array}$ & $\begin{array}{c}6.11 \\
\pm 0.11^{\mathrm{bA}}\end{array}$ & $\begin{array}{c}6.66 \\
\pm 1.19^{\mathrm{abB}}\end{array}$ & $\begin{array}{c}7.19 \\
\pm 0.01^{\mathrm{aA}}\end{array}$ & $\begin{array}{c}6.20 \\
\pm 0.02^{\mathrm{aB}}\end{array}$ & $\begin{array}{c}6.34 \\
\pm 0.59^{\mathrm{cB}}\end{array}$ & $\begin{array}{c}3.39 \\
\pm 0.02^{\mathrm{aA}}\end{array}$ & $\begin{array}{c}62.57 \\
\pm 1.35^{\mathrm{abB}}\end{array}$ & $\begin{array}{c}67.69 \\
\pm 3.4^{\mathrm{bcA}}\end{array}$ & $\begin{array}{c}126.71 \\
\pm 2.13^{\mathrm{bA}}\end{array}$ & $\begin{array}{r}199.60 \\
\pm 6.11^{\mathrm{aB}}\end{array}$ \\
\hline $\mathrm{CB}+\mathrm{S}$ & $\begin{array}{c}64.8 \\
\pm 0.27^{\mathrm{aB}}\end{array}$ & $\begin{array}{c}56.00 \\
\pm 0.22^{\mathrm{aA}}\end{array}$ & $\begin{array}{c}18.00 \\
\pm 0.76^{\mathrm{aB}}\end{array}$ & $\begin{array}{c}16.25 \\
\pm 1.25^{\mathrm{aA}}\end{array}$ & $\begin{array}{c}6.19 \\
\pm 0.28^{\mathrm{bA}}\end{array}$ & $\begin{array}{c}6.99 \\
\pm 0.29^{\mathrm{bB}}\end{array}$ & $\begin{array}{c}7.64 \\
\pm 0.01^{\mathrm{eA}}\end{array}$ & $\begin{array}{c}6.77 \\
\pm 0.01^{\mathrm{bB}}\end{array}$ & $\begin{array}{c}5.09 \\
\pm 0.28^{\mathrm{aB}}\end{array}$ & $\begin{array}{c}4.66 \\
\pm 0.03^{\mathrm{dA}}\end{array}$ & $\begin{array}{c}63.08 \\
\pm 0.66^{\mathrm{bB}}\end{array}$ & $\begin{array}{c}65.33 \\
\pm 1.74^{\mathrm{abA}}\end{array}$ & $\begin{array}{c}130.97 \\
\pm 1.08^{\mathrm{bA}}\end{array}$ & $\begin{array}{l}187.76 \\
\pm 0.9^{\mathrm{aB}}\end{array}$ \\
\hline
\end{tabular}

${ }^{¥}$ : see materials and methods, table 1 ,

dw: values were calculated on dry weight basis,

fw: values were calculated on fresh weight basis,

RTU: ready-to-use, RTE: ready-to-eat,

a, b, c, $\ldots:$ means with the same letter in the same column are not significantly different $(p>0.05)$,

A, B, C, ... means with the same letter in the same raw into each parameter are not significantly different $(p>0.05)$. 
with spirulina and before frying cooking as portrayed in $\mathrm{CB}+\mathrm{S}$ formulas to be $28.36 \mu \mathrm{mol} \mathrm{TE} \mathrm{g}^{-}$ 1. The content of TPC and relative antioxidant activity in different OVDs shows different significances pattern in both RTU and RTE OVDs as a result of cooking method impact (Gertz et al., 2000; Turkmen et al., 2005; Barakat, 2013; Barakat, 2014; Barakat and Rohn, 2014). A significant loss of flavonoids content was observed in RTE CVDs when compared to RTU ones. The total flavonoids loss was varied according to the kind of vegetables. Howver, they were lossing with half degree of deteroration after frying. Carotenoids have been extensively studied for their potential protection against numerous cancer diseases. In recent years, several reports on the retention of total carotenoids in cooked vegetables are available (Zhang and Hamauzu, 2004; Gliszczynska-Swiglo et al., 2006; Yuan et al., 2009). In all diets, the formulation of OVDs incorporating different vegetables exhibit rich carotenoids content, a result of increasing the carotenoids content in chickpeas grains (Segev, 2011). It is presented herein that, flavonoids and flavonols were retained by 66 and $64 \%$, respectively. The retained content may depends on initial flavonoids and flavonols content, vegetable structure or diet matrix, and leaching of flavonoids and flavonols and its derivatives into the oil followed by thermal degradation during frying cooking, being similar to reports by (Zhang and Hamauzu, 2004; Buchner et al., 2006; Yuan et al., 2009; Barakat, 2013; Barakat, 2014; Barakat and Rohn, 2014).

\subsection{Amino acid content of spirulina and innovative ready-to-use and ready-to-eat OVDs}

The amino acid composition of spirulina and some slected RTU and RTE OVDs is given in Table 5. It is clear that the amount of many EAA in spirulina matched (Isoleucine) or exceeded (Therionine, Valine, Leucine and Tyrosine) their corresponding quantities in egg's protein as a standard. This property make these spirulina an excellent source of protein supplementing for other foods which are low in Isoleucine, Therionine, Valine, Leucine and Tyrosine. The addition of spirulina with $1 \%$ to RTU OVDs led to an increase in all EAA. From the obtained results, it could be observed that $\mathrm{CP}+\mathrm{SR}$ was the highest in all EAA than the other treatments. Then leusine, phenyalanine, and valine recorded the highest EAA amount of all treatments. The aspartic and glutamic amino acids constituted the major portion in spirulina and all treatments, it shows a value of 0.638 and $0.825,0.539$ and $0.893,0.641$ and 1.037, 0.574 and 0.920 and 0.602 and $0.991 \mathrm{~g} \mathrm{~g}^{-1}$ nitrogen in spirulina, $\mathrm{CP}-\mathrm{SR}, \mathrm{CP}+\mathrm{SR}, \mathrm{CP}-\mathrm{SF}$ and $\mathrm{CP}+\mathrm{SF}$, respectively.
Data in Table 6 shows the nutritional evaluation of spirulina and some slected RTU and RTE OVDs. Total essential amino acids (TEAA), total nonessential amino acids (TNEAA) (g $\left.16 \mathrm{~g}^{-1} \mathrm{~N}\right)$, ratio of EAA:protein and EAAI $(\%)$ in spirulina were higher than those of egg, which contained 45.46,

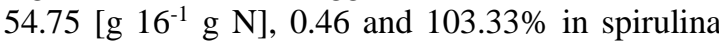
compared with 44.06, 47.04 [g $16 \mathrm{~g}^{-1} \mathrm{~N}$ ], 0.44 and $100 \%$ in egg. From the results, it could be observed that $\mathrm{CP}+\mathrm{SR}$ and $\mathrm{CP}+\mathrm{SF}$ had the highest amount of EAA, ratios of E:N, E:P and EAAI (\%), which

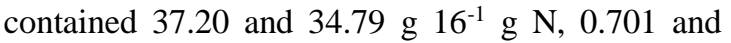
0.698 for $\mathrm{E}: \mathrm{N}$ ratio, 0.372 and 0.348 for $\mathrm{E}: \mathrm{P}$ ratio and 85.00 and $79.34 \%$ for EAAI. Thus, it was recorded lower than egg protein according to FAO (1970). Assessment of amino acids level individually to total essential amino acids had been illustrated in Table 7. As recommended by FAO and WHO, there are two categories being very important for determining the protein quality, one of them depends on calculating individual (A) to essential (E) amino acids ratios. Ratios for tested protein as well as these for different FAO patterens, hen's egg [FAO 1970] (control ratio) are presented in Table 7. From these results, it could be noticed that lysine was the most deficient amino acid in spirulina and both RTU and RTE OVDs compared with hens egg. The lower ratios than control were observed for therionine and isoleucine in all treatments, while the phenylalanine and histidine in spirulina were lower than control. Although differed greatly, the ratios for other essential amino acids matched or exceeded the corresponding ratios of control. Data in Table 8 illustrate the certain amino acids of spirulina and some slected RTU and RTE OVDs and compared to FAO pattern $\mathrm{mg} \mathrm{g}^{-1}$ protein. With regard to limiting amino acids, it could be noticed that the histidine is the most deficient and the first limiting amino acid in spirulina, while the first limiting amino acid was lysine in all treatments. The second limiting amino acid in spirulina was lysine, while it was therionine in all treatments. The third limiting amino acid was leucine in CP-SR and CP-SF treatments, while it was histidine in $\mathrm{CP}+\mathrm{SF}$ treatments.

\subsection{Organoleptic properties of innovative ready- to-eat chickpea-based OVDs}

Organoleptic properties of food products are an important criterion by which its consumer acceptability can be assessed. The organoleptic properties of RTE OVDs based on a seven-point hedonic scale showed that most of fried diets recorded mean scores higher than 4 (acceptable score) for all tested parameters, Table 9. However, the incorporation of spirulina led to decrease the acceptability of them to be low than 4 in $\mathrm{CB}+\mathrm{S}$ and $\mathrm{CP}+\mathrm{S}$. 
Table 3. Minerals content of innovative read-to-use and read-to-eat chickpea-based ovo-vegetarian diets incorporating different vegetables and supplemented with spirulina.

\begin{tabular}{|c|c|c|c|c|c|c|c|c|c|c|c|c|c|c|c|c|c|c|}
\hline \multirow{3}{*}{ Recipes $^{¥}$} & \multicolumn{18}{|c|}{ Minerals content $\left(\mathrm{mg} 100 \mathrm{~g}^{-1 \mathrm{dw}}\right)$} \\
\hline & \multicolumn{2}{|c|}{ Sodium } & \multicolumn{2}{|c|}{ Potassium } & \multicolumn{2}{|c|}{ Calcium } & \multicolumn{2}{|c|}{ Phosphorus } & \multicolumn{2}{|c|}{ Magnesium } & \multicolumn{2}{|c|}{ Iron } & \multicolumn{2}{|c|}{ Copper } & \multicolumn{2}{|c|}{ Manganese } & \multicolumn{2}{|c|}{ Zinc } \\
\hline & RTU & RTE & RTU & RTE & RTU & RTE & RTU & RTE & RTU & RTE & RTU & RTE & RTU & RTE & RTU & RTE & RTU & RTE \\
\hline $\mathrm{CP}-\mathrm{S}$ & $\begin{array}{l}1767.2 \\
\pm 0.5^{\mathrm{aB}}\end{array}$ & $\begin{array}{l}1698.5 \\
\pm 0.5^{\mathrm{aA}}\end{array}$ & $\begin{array}{l}1410.2 \\
\pm 2.3^{\mathrm{aA}}\end{array}$ & $\begin{array}{l}1496.47 \\
\pm 1.78^{\mathrm{aA}}\end{array}$ & $\begin{array}{l}1413.77 \\
\pm 0.45^{\mathrm{aB}}\end{array}$ & $\begin{array}{c}1237.6 \\
7 \pm 0.45^{\text {aA }}\end{array}$ & $\begin{array}{c}141.83 \\
\pm 0.21^{\mathrm{aA}}\end{array}$ & $\begin{array}{c}173.13 \\
\pm 0.21^{\mathrm{dB}}\end{array}$ & $\begin{array}{c}116.57 \\
\pm 1.58^{\mathrm{dB}}\end{array}$ & $\begin{array}{c}91.93 \\
\pm 1.05^{\mathrm{eA}}\end{array}$ & $\begin{array}{c}663 \\
\pm 1.3^{\mathrm{eB}}\end{array}$ & $\begin{array}{c}501.47 \\
\pm 6.64^{\mathrm{dA}}\end{array}$ & $\begin{array}{c}31.7 \\
\pm 2.25^{\mathrm{bA}}\end{array}$ & $\begin{array}{c}31.38 \\
\pm 2.16^{\mathrm{bA}}\end{array}$ & $\begin{array}{c}27.73 \\
\pm 1.35^{\mathrm{aA}}\end{array}$ & $\begin{array}{c}72.63 \\
\pm 1.35^{\mathrm{bA}}\end{array}$ & $\begin{array}{c}79.23 \\
\pm 1.35^{\mathrm{dB}}\end{array}$ & $\begin{array}{c}70 \\
\pm 1.3^{\mathrm{bA}}\end{array}$ \\
\hline $\mathrm{CP}+\mathrm{S}$ & $\begin{array}{l}2117.47 \\
\pm 0.55^{\mathrm{cB}}\end{array}$ & $\begin{array}{l}1811.57 \\
\pm 0.55^{\mathrm{dA}}\end{array}$ & $\begin{array}{l}1868.1 \\
\pm 1.1^{\mathrm{dB}}\end{array}$ & $\begin{array}{l}1653.67 \\
\pm 1.72^{\mathrm{bA}}\end{array}$ & $\begin{array}{l}1851.97 \\
\pm 0.45^{\mathrm{dB}}\end{array}$ & $\begin{array}{l}1466.93 \\
\pm 0.45^{\mathrm{bA}}\end{array}$ & $\begin{array}{c}168.5 \\
\pm 0.26^{\mathrm{cB}}\end{array}$ & $\begin{array}{c}159.47 \\
\pm 2.12^{\mathrm{bA}}\end{array}$ & $\begin{array}{c}101.43 \\
\pm 1.05^{\mathrm{bB}}\end{array}$ & $\begin{array}{c}39.47 \\
\pm 1.27^{\mathrm{aA}}\end{array}$ & $\begin{array}{l}676.23 \\
\pm 1.35^{\mathrm{fB}}\end{array}$ & $\begin{array}{c}420 \\
\pm 1.3^{\mathrm{bA}}\end{array}$ & $\begin{array}{c}39.2 \\
\pm 2.76^{\mathrm{cA}}\end{array}$ & $\begin{array}{c}37.42 \\
\pm 2.12^{\mathrm{cA}}\end{array}$ & $\begin{array}{c}52.83 \\
\pm 1.35^{\mathrm{bA}}\end{array}$ & $\begin{array}{c}178.3 \\
\pm 1.3^{\mathrm{dB}}\end{array}$ & $\begin{array}{c}69.57 \\
\pm 1.99^{\mathrm{aA}}\end{array}$ & $\begin{array}{c}73.97 \\
\pm 1.35^{\mathrm{cB}}\end{array}$ \\
\hline CT-S & $\begin{array}{l}1909.47 \\
\pm 0.29^{\mathrm{bB}}\end{array}$ & $\begin{array}{l}1831.03 \\
\pm 0.45^{\mathrm{dA}}\end{array}$ & $\begin{array}{l}1601.37 \\
\pm 1.15^{\mathrm{cA}}\end{array}$ & $\begin{array}{l}2081.87 \\
\pm 1.58^{\mathrm{dB}}\end{array}$ & $\begin{array}{l}1634.53 \\
\pm 0.23^{\mathrm{cB}}\end{array}$ & $\begin{array}{l}1446.07 \\
\pm 0.29^{\mathrm{bA}}\end{array}$ & $\begin{array}{l}148.63 \\
\pm 0.5^{\text {aA }}\end{array}$ & $\begin{array}{c}145.43 \\
\pm 0.97^{\mathrm{aA}}\end{array}$ & $\begin{array}{c}97.9 \\
\pm 4.97^{\mathrm{bA}}\end{array}$ & $\begin{array}{l}132.07 \\
\pm 1.48^{\mathrm{fB}}\end{array}$ & $\begin{array}{c}287.9 \\
\pm 1.3^{\mathrm{aA}}\end{array}$ & $\begin{array}{c}468.13 \\
\pm 19.81^{\mathrm{cB}}\end{array}$ & $\begin{array}{c}27.73 \\
\pm 1.35^{\mathrm{aB}}\end{array}$ & $\begin{array}{c}24.45 \\
\pm 1.48^{\mathrm{aA}}\end{array}$ & $\begin{array}{c}83.2 \\
\pm 1.3^{\mathrm{cA}}\end{array}$ & $\begin{array}{c}99.87 \\
\pm 4.38^{\mathrm{cB}}\end{array}$ & $\begin{array}{c}73.97 \\
\pm 1.35^{\mathrm{bB}}\end{array}$ & $\begin{array}{c}62.57 \\
\pm 2.91^{\mathrm{aA}}\end{array}$ \\
\hline $\mathrm{CT}+\mathrm{S}$ & $\begin{array}{l}1960.93 \\
\pm 0.29^{\mathrm{bB}}\end{array}$ & $\begin{array}{l}1701.17 \\
\pm 0.55^{\mathrm{cA}}\end{array}$ & $\begin{array}{l}1961.97 \\
\pm 1.15^{\mathrm{eB}}\end{array}$ & $\begin{array}{l}1410.63 \\
\pm 1.33^{\mathrm{aA}}\end{array}$ & $\begin{array}{l}1678.53 \\
\pm 0.29^{\mathrm{cB}}\end{array}$ & $\begin{array}{l}1490.13 \\
\pm 0.29^{\mathrm{bA}}\end{array}$ & $\begin{array}{l}157.13 \\
\pm 0.7^{\mathrm{bB}}\end{array}$ & $\begin{array}{c}147.67 \\
\pm 0.55^{\mathrm{aA}}\end{array}$ & $\begin{array}{c}97.93 \\
\pm 1.58^{\mathrm{bB}}\end{array}$ & $\begin{array}{c}43.33 \\
\pm 1.05^{\mathrm{bA}}\end{array}$ & $\begin{array}{c}589.93 \\
\pm 13.38^{\mathrm{dB}}\end{array}$ & $\begin{array}{c}467.57 \\
\pm 1.35^{\mathrm{cA}}\end{array}$ & $\begin{array}{c}30.4 \\
\pm 1.3^{\mathrm{bA}}\end{array}$ & $\begin{array}{c}29.94 \\
\pm 1.4^{\mathrm{bA}}\end{array}$ & $\begin{array}{c}81.9 \\
\pm 1.3^{\mathrm{cB}}\end{array}$ & $\begin{array}{c}33.00 \\
\pm 1.3^{\mathrm{aA}}\end{array}$ & $\begin{array}{c}76.6 \\
\pm 1.3^{\mathrm{cB}}\end{array}$ & $\begin{array}{c}70.87 \\
\pm 0.75^{\mathrm{bA}}\end{array}$ \\
\hline CB-S & $\begin{array}{l}2208.87 \\
\pm 0.55^{\mathrm{dB}}\end{array}$ & $\begin{array}{l}1990.67 \\
\pm 0.55^{\mathrm{eA}}\end{array}$ & $\begin{array}{l}1970.37 \\
\pm 1.78^{\mathrm{eA}}\end{array}$ & $\begin{array}{l}1928.77 \\
\pm 1.15^{\mathrm{cA}}\end{array}$ & $\begin{array}{l}1890.77 \\
\pm 0.45^{\mathrm{dB}}\end{array}$ & $\begin{array}{l}1419.73 \\
\pm 0.45^{\mathrm{bA}}\end{array}$ & $\begin{array}{l}165.73 \\
\pm 0.6^{\mathrm{cB}}\end{array}$ & $\begin{array}{c}145.6 \\
\pm 0.61^{\mathrm{aA}}\end{array}$ & $\begin{array}{c}82.43 \\
\pm 1.85^{\mathrm{aB}}\end{array}$ & $\begin{array}{c}63.07 \\
\pm 1.63^{\mathrm{cA}}\end{array}$ & $\begin{array}{l}311.7 \\
\pm 1.3^{\mathrm{bA}}\end{array}$ & $\begin{array}{l}385.63 \\
\pm 3.5^{\mathrm{aB}}\end{array}$ & $\begin{array}{c}27.73 \\
\pm 1.35^{\mathrm{aA}}\end{array}$ & $\begin{array}{c}26.86 \\
\pm 1.46^{\mathrm{aA}}\end{array}$ & $\begin{array}{c}232.47 \pm \\
1.35^{\mathrm{dB}}\end{array}$ & $\begin{array}{c}90.67 \\
\pm 0.75^{\mathrm{cA}}\end{array}$ & $\begin{array}{c}73.53 \\
\pm 0.81^{\mathrm{bB}}\end{array}$ & $\begin{array}{c}71.3 \\
\pm 1.3^{\mathrm{bA}}\end{array}$ \\
\hline $\mathrm{CB}+\mathrm{S}$ & $\begin{array}{l}1792.03 \\
\pm 0.55^{\mathrm{bB}}\end{array}$ & $\begin{array}{c}1773 \pm \\
0.5^{\mathrm{bA}}\end{array}$ & $\begin{array}{l}1529.3 \\
\pm 2.3^{\mathrm{bA}}\end{array}$ & $\begin{array}{l}1697.53 \\
\pm 1.15^{\mathrm{bB}}\end{array}$ & $\begin{array}{l}1533.97 \\
\pm 0.45^{\mathrm{bA}}\end{array}$ & $\begin{array}{l}1533.97 \\
\pm 0.45^{\mathrm{cA}}\end{array}$ & $\begin{array}{c}177.8 \\
\pm 0.53^{\mathrm{dB}}\end{array}$ & $\begin{array}{c}160.33 \\
\pm 0.84^{\mathrm{cA}}\end{array}$ & $\begin{array}{c}103.2 \\
\pm 2.66^{\mathrm{cB}}\end{array}$ & $\begin{array}{c}70.77 \\
\pm 1.05^{\mathrm{dA}}\end{array}$ & $\begin{array}{c}494.83 \\
\pm 13.03^{\mathrm{cA}}\end{array}$ & $\begin{array}{l}540.2 \\
\pm 1.3^{\mathrm{eB}}\end{array}$ & $\begin{array}{c}42.7 \\
\pm 4.03^{\mathrm{dA}}\end{array}$ & $\begin{array}{c}40.06 \\
\pm 3.12^{\mathrm{dA}}\end{array}$ & $\begin{array}{c}44.9 \\
\pm 1.3^{\mathrm{bA}}\end{array}$ & $\begin{array}{c}88.5 \\
\pm 2.25^{\mathrm{cB}}\end{array}$ & $\begin{array}{c}83.2 \\
\pm 1.3^{\mathrm{eB}}\end{array}$ & $\begin{array}{c}70 \\
\pm 1.3^{\mathrm{bA}}\end{array}$ \\
\hline
\end{tabular}

${ }^{¥}$ : see materials and methods, table 1 ,

dw: values were calculated on dry weight basis,

RTU: ready-to-use, RTE: ready-to-eat,

a, b, c, ...: means with the same letter in the same column are not significantly different $(p>0.05)$,

A, B, C, $\ldots:$ means with the same letter in the same raw into each parameter are not significantly different $(p>0.05)$ 
Table 4. Ascorbic acid, total phenolic compounds (TPC) and antioxidant activity, total flavonoid and total flavonols of innovative read-to-use and read-to-eat chickpea-based ovo-vegetarian diets incorporating different vegetables and supplemented with spirulina

\begin{tabular}{|c|c|c|c|c|c|c|c|c|c|c|}
\hline \multirow[t]{2}{*}{ Recipes $^{¥}$} & \multicolumn{2}{|c|}{ 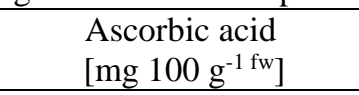 } & \multicolumn{2}{|c|}{$\begin{array}{c}\text { TPC } \\
{\left[\mathrm{mg} \mathrm{g}^{-1 \mathrm{dw}}\right]}\end{array}$} & \multicolumn{2}{|c|}{$\begin{array}{c}\text { Antioxidant activity } \\
{\left[\mu \mathrm{mol} \mathrm{TE} \mathrm{g} \mathrm{g}^{-1 \mathrm{dw}}\right]}\end{array}$} & \multicolumn{2}{|c|}{$\begin{array}{l}\text { Total flavonoids } \\
{\left[\mathrm{mg} \mathrm{QE} \mathrm{g}^{-1 \mathrm{dw}}\right]}\end{array}$} & \multicolumn{2}{|c|}{$\begin{array}{l}\text { Total flavonols } \\
{\left[\mathrm{mg} \mathrm{QE} \mathrm{g}^{-1 \mathrm{dw}}\right]}\end{array}$} \\
\hline & RTU & RTE & RTU & RTE & RTU & RTE & RTU & RTE & RTE & RTU \\
\hline CP-S & $\begin{array}{c}54.00 \\
\pm 0.63^{\mathrm{aB}}\end{array}$ & $\begin{aligned} & 3.73 \\
\pm & 1.27^{\mathrm{aA}}\end{aligned}$ & $\begin{array}{c}64.68 \\
\pm 5.04^{\mathrm{aB}}\end{array}$ & $\begin{array}{c}56.61 \\
\pm 4.43^{\mathrm{aA}}\end{array}$ & $\begin{array}{c}51.04 \\
\pm 6.77^{\mathrm{bA}}\end{array}$ & $\begin{array}{c}61.65 \\
\pm 12.01^{\mathrm{bB}}\end{array}$ & $\begin{array}{c}25.73 \\
\pm 1.04^{\mathrm{aB}}\end{array}$ & $\begin{array}{c}16.21 \\
\pm 0.14^{\mathrm{aA}}\end{array}$ & $\begin{array}{l}11.03 \\
\pm 0.3^{\mathrm{aB}}\end{array}$ & $\begin{array}{r}9.46 \\
\pm 0.09^{\mathrm{bcA}}\end{array}$ \\
\hline $\mathrm{CP}+\mathrm{S}$ & $\begin{array}{c}69.40 \\
\pm 6.87^{\mathrm{aB}}\end{array}$ & $\begin{array}{c}5.16 \\
\pm 0.62^{\mathrm{aA}}\end{array}$ & $\begin{array}{c}65.87 \\
\pm 1.53^{\mathrm{abB}}\end{array}$ & $\begin{array}{c}58.11 \\
\pm 3.68^{\mathrm{aA}}\end{array}$ & $\begin{array}{c}70.42 \\
\pm 2.75^{\mathrm{dB}}\end{array}$ & $\begin{array}{c}61.14 \\
\pm 9.53^{\mathrm{bA}}\end{array}$ & $\begin{array}{l}23.41 \\
\pm 0.3^{\mathrm{aA}}\end{array}$ & $\begin{array}{c}20.61 \\
\pm 3.57^{\mathrm{aA}}\end{array}$ & $\begin{array}{c}10.83 \\
\pm 0.16^{\mathrm{aB}}\end{array}$ & $\begin{array}{c}9.49 \\
\pm 0.35^{\mathrm{bcA}}\end{array}$ \\
\hline CT-S & $\begin{array}{c}44.85 \\
\pm 6.89^{\mathrm{aB}}\end{array}$ & $\begin{array}{c}4.94 \\
\pm 1.28^{\mathrm{aA}}\end{array}$ & $\begin{array}{c}59.84 \\
\pm 2.25^{\mathrm{aB}}\end{array}$ & $\begin{array}{c}52.81 \\
\pm 2.04^{\mathrm{aA}}\end{array}$ & $\begin{array}{c}47.77 \\
\pm 3.26^{\mathrm{bB}}\end{array}$ & $\begin{array}{c}39.58 \\
\pm 9.78^{\mathrm{aA}}\end{array}$ & $\begin{array}{c}18.47 \\
\pm 0.99^{\mathrm{aA}}\end{array}$ & $\begin{array}{c}19.16 \\
\pm 3.88^{\mathrm{aA}}\end{array}$ & $\begin{array}{c}11.39 \\
\pm 0.15^{\mathrm{bB}}\end{array}$ & $\begin{array}{c}9.42 \\
\pm 0.02^{\mathrm{bcA}}\end{array}$ \\
\hline $\mathrm{CT}+\mathrm{S}$ & $\begin{array}{l}108.10 \\
\pm 44^{\mathrm{cB}}\end{array}$ & $\begin{array}{c}4.59 \\
\pm 1.47^{\mathrm{aA}}\end{array}$ & $\begin{array}{c}81.70 \\
\pm 28.56^{\mathrm{bcB}}\end{array}$ & $\begin{array}{c}56.6 \\
\pm 1.4^{\mathrm{aA}}\end{array}$ & $\begin{array}{c}64.04 \\
\pm 31.36^{\mathrm{cA}}\end{array}$ & $\begin{array}{c}66.5 \\
\pm 3.41^{\mathrm{bA}}\end{array}$ & $\begin{array}{c}65.59 \\
\pm 22.12^{\mathrm{cB}}\end{array}$ & $\begin{array}{c}37.14 \\
\pm 1.14^{\mathrm{bA}}\end{array}$ & $\begin{array}{c}11.61 \\
\pm 0.18^{\mathrm{bcB}}\end{array}$ & $\begin{array}{c}8.76 \\
\pm 0.96^{\mathrm{aA}}\end{array}$ \\
\hline CB-S & $\begin{array}{c}51.27 \\
\pm 8.65^{\mathrm{aB}}\end{array}$ & $\begin{array}{c}3.84 \\
\pm 1.28^{\mathrm{aA}}\end{array}$ & $\begin{array}{l}75.45 \\
\pm 3^{\mathrm{bB}}\end{array}$ & $\begin{array}{c}52.11 \\
\pm 0.55^{\mathrm{aA}}\end{array}$ & $\begin{array}{c}34.54 \\
\pm 2.93^{\mathrm{aA}}\end{array}$ & $\begin{array}{c}46.33 \\
\pm 6.19^{\mathrm{aB}}\end{array}$ & $\begin{array}{c}53.4 \\
\pm 0.91^{\mathrm{bB}}\end{array}$ & $\begin{array}{c}30.38 \\
\pm 0.44^{\mathrm{bA}}\end{array}$ & $\begin{array}{c}11.38 \\
\pm 0.28^{\mathrm{bB}}\end{array}$ & $\begin{array}{c}9.06 \\
\pm 0.11^{\mathrm{bA}}\end{array}$ \\
\hline $\mathrm{CB}+\mathrm{S}$ & $\begin{array}{c}62.96 \\
\pm 8.14^{\mathrm{bB}}\end{array}$ & $\begin{array}{c}3.67 \\
\pm 0.64^{\mathrm{aA}}\end{array}$ & $\begin{array}{c}65.48 \\
\pm 5.06^{\mathrm{abA}}\end{array}$ & $\begin{array}{c}70.62 \\
\pm 4.51^{\mathrm{bA}}\end{array}$ & $\begin{array}{c}28.36 \\
\pm 5.88^{\mathrm{aA}}\end{array}$ & $\begin{array}{c}39.87 \\
\pm 6.54^{\mathrm{aB}}\end{array}$ & $\begin{array}{c}56.81 \\
\pm 11.18^{\mathrm{bB}}\end{array}$ & $\begin{array}{c}38.16 \\
\pm 2.86^{\mathrm{bA}}\end{array}$ & $\begin{array}{c}10.9 \\
\pm 0.08^{\mathrm{aB}}\end{array}$ & $\begin{array}{c}9.25 \\
\pm 0.09^{\mathrm{bA}}\end{array}$ \\
\hline
\end{tabular}

: see materials and methods, table 1 ,

dw: values were calculated on dry weight basis,

fw: values were calculated on fresh weight basis,

RTU: ready-to-use, RTE: ready-to-eat,

a, b, c, ... means with the same letter in the same column are not significantly different $(p>0.05)$

A, B, C, ... means with the same letter in the same raw into each parameter are not significantly different $(p>0.05)$. 
Table 5. Amino acid composition of spirulina and some innovative RTU and RTE OVDs incorporating different vegetables and supplemented with spirulina $\left(\mathrm{g} \mathrm{g}^{-1} \mathrm{~N}\right)$ compared with standard protein and amino acids scores.

\begin{tabular}{|c|c|c|c|c|c|c|}
\hline \multirow{2}{*}{ Amino acids } & \multirow{2}{*}{ Spirulina } & \multicolumn{4}{|c|}{ Recipes $^{¥}$} & \multirow{2}{*}{$\begin{array}{c}\text { Hens egg FAO } \\
(1970)\end{array}$} \\
\hline & & CP-SR & CP-SF & $\mathrm{CP}+\mathrm{SR}$ & $\mathrm{CP}+\mathrm{SF}$ & \\
\hline Therionine & 0.326 & 0.191 & 0.202 & 0.220 & 0.231 & 0.320 \\
\hline Valine & 0.452 & 0.292 & 0.304 & 0.355 & 0.334 & 0.428 \\
\hline Isoleucine & 0.380 & 0.229 & 0.242 & 0.250 & 0.246 & 0.393 \\
\hline Leucine & 0.577 & 0.379 & 0.414 & 0.443 & 0.423 & 0.551 \\
\hline Tyrosine & 0.341 & 0.220 & 0.238 & 0.256 & 0.237 & 0.260 \\
\hline Phenylalanine & 0.323 & 0.310 & 0.326 & 0.366 & 0.344 & 0.358 \\
\hline Lysine & 0.320 & 0.235 & 0.255 & 0.275 & 0.237 & 0.436 \\
\hline Histidine & 0.112 & 0.122 & 0.131 & 0.150 & 0.122 & 0.112 \\
\hline Aspartic & 0.638 & 0.539 & 0.574 & 0.641 & 0.602 & 0.601 \\
\hline Serine & 0.323 & 0.245 & 0.263 & 0.286 & 0.280 & 0.796 \\
\hline Glutamic & 0.825 & 0.893 & 0.920 & 1.037 & 0.991 & 0.478 \\
\hline Proline & 0.267 & 0.354 & 0.303 & 0.311 & 0.341 & 0.260 \\
\hline Glycine & 0.336 & 0.210 & 0.235 & 0.242 & 0.243 & 0.207 \\
\hline Alanine & 0.563 & 0.263 & 0.284 & 0.286 & 0.280 & 0.370 \\
\hline Argenine & 0.460 & 0.379 & 0.440 & 0.516 & 0.377 & 0.381 \\
\hline Total of EAA & 2.841 & 1.978 & 2.112 & 2.325 & 2.174 & 3.218 \\
\hline Total of N-EAA & 3.422 & 2.883 & 3.020 & 3.319 & 3.114 & 3.093 \\
\hline Total of amino acids & 6.263 & 4.861 & 5.132 & 5.644 & 5.288 & 6.311 \\
\hline
\end{tabular}

¥: see materials and methods, table 1 ,

EAA: Essential amino acids. N-EAA: Non-essential amino acid.

Table 6. The nutritional evaluation of spirulina and some innovative RTU and RTE OVDs's proteins.

\begin{tabular}{lcccccc}
\hline \multirow{2}{*}{ Recipes $^{¥}$} & \multicolumn{7}{c}{ Item } \\
\cline { 2 - 7 } & ${\text { EAA g } 16 \mathrm{~g} \mathrm{~g}^{-1} \mathrm{~N}}^{\text {Sp-EAA g } 16 \mathrm{~g} \mathrm{~g}^{-1} \mathrm{~N}}$ & E:N ratio & E:T ratio & E:P ratio & EAAI (\%) \\
\hline Spirulina & 45.456 & 54.752 & 0.830 & 0.454 & 0.455 & 103.33 \\
CP-SR & 31.648 & 46.128 & 0.686 & 0.407 & 0.316 & 71.13 \\
CP-SF & 33.792 & 48.320 & 0.699 & 0.412 & 0.338 & 77.82 \\
CP+SR & 37.20 & 53.104 & 0.701 & 0.412 & 0.372 & 84.85 \\
CP+SF & 34.784 & 49.824 & 0.698 & 0.411 & 0.348 & 79.34 \\
\hline Egg FAO (1970) & 44.060 & 47.040 & 0.940 & 0.484 & 0.440 & 100.00 \\
Beef FAO (1970) & 42.724 & 57.276 & 0.746 & 0.427 & 0.427 & 79.55 \\
\hline
\end{tabular}

¥: see materials and methods, table 1 ,

E:N-Ratio of essential amino acids to non-essential amino acids.

E:T-Ratio of essential amino acids to total amino acids.

E:P-Ratio of essential amino acids to protein.

EAAI-Essential amino acid index according to Oser (1959).

Table 7. Assessment of individual amino acids of spirulina and some innovative RTU and RTE OVDs's proteins

to references essential amino acids in hen's egg protein [mg individual AA g-1 TEAA].

\begin{tabular}{lcccccc}
\hline \multirow{2}{*}{ Amino acids } & \multirow{2}{*}{ Spirulina } & \multicolumn{4}{c}{ Recipes $^{\ddagger}$} & $\begin{array}{c}\text { Hens egg score } \\
\text { (FAO 1970) }\end{array}$ \\
\cline { 3 - 6 } & & CP-SR & CP-SF & SP+SR & CP+SF & 110.42 \\
Therionine & 119.4 & 96.56 & 95.64 & 94.49 & 106.30 & 147.69 \\
Valine & 151.03 & 147.62 & 143.94 & 152.67 & 153.70 & 135.61 \\
Isoleucine & 135.04 & 115.77 & 114.58 & 111.99 & 113.21 & 190.13 \\
Leucine & 205.05 & 191.61 & 196.02 & 190.29 & 194.66 & 89.72 \\
Tyrosine & 121.18 & 111.22 & 112.69 & 110.24 & 109.07 & 123.53 \\
Phenylalanine & 114.78 & 156.72 & 154.36 & 157.48 & 157.85 & 150.45 \\
Lysine & 113.72 & 118.81 & 120.74 & 118.11 & 109.07 & 52.45 \\
Histidine & 39.80 & 61.68 & 62.03 & 64.74 & 56.14 & \\
\hline
\end{tabular}

: see materials and methods, table 1 ,

A/E Ratio: mg amino acid per gram of total essential amino acids. 
Table 8. Scores of essential amino acids to limiting the three essential amino acids responsible for limiting the quality of protein of formulated OVDs.

\begin{tabular}{|c|c|c|c|c|c|c|}
\hline \multirow{2}{*}{ Amino acids } & \multicolumn{5}{|c|}{ Recipes $^{\ddagger}$} & \multirow{2}{*}{$\begin{array}{c}\text { Pattern } \\
\mathrm{mg} \mathrm{g}^{-1} \\
\text { protein* }\end{array}$} \\
\hline & Spirulina & $\mathrm{Cp}-\mathrm{SR}$ & $\mathrm{Cp}-\mathrm{SF}$ & $\mathrm{Cp}+\mathrm{SR}$ & $\mathrm{Cp}+\mathrm{SF}$ & \\
\hline Therionine & 134.45 & $\underline{76.48}$ & $\underline{80.90}$ & $\underline{87.77}$ & 92.37 & 40 \\
\hline Valine & 144.65 & 93.28 & $\overline{97.08}$ & 113.52 & 106.95 & 50 \\
\hline Isoleucine & 151.97 & 91.52 & 96.56 & 103.86 & 98.44 & 40 \\
\hline Leucine & 131.88 & $\underline{86.69}$ & 94.69 & 101.15 & 96.53 & 70 \\
\hline Tyrosine & 156.02 & $\overline{100.30}$ & $\overline{108.86}$ & 117.03 & 108.34 & 35 \\
\hline Phenylalanine & 107.75 & 103.44 & 108.73 & 121.90 & 114.45 & 48 \\
\hline Lysine & 92.91 & $\underline{68.39}$ & 74.02 & $\underline{79.79}$ & $\underline{68.94}$ & 35 \\
\hline Histidine & 85.37 & $\overline{93.14}$ & $\overline{99.41}$ & $\overline{114.24}$ & $\overline{92.60}$ & 21 \\
\hline First AA & Histidine & Lysine & Lysine & Lysine & $\overline{\text { Lysine }}$ & \\
\hline Second AA & Lysine & Therionine & Therionine & Therionine & Therionine & \\
\hline Third AA & - & Leucine & Leucine & - & Histidine & \\
\hline
\end{tabular}

$¥$ : see materials and methods, table 1 ,

* According to FAO/WHO AD HOC Committee (FAO, 1973).

Amino acid score according to FAO $(1973)=\frac{\mathrm{mg} \text { amino acid in } 1 \mathrm{~g} \text { protein }}{\mathrm{mg} \text { amino acid sugested by FAO/WHO }} \times 100$

Under line preferred that the lowest percentage compared to FAO pattern.

The appearance of RTE OVDs showed higher mean scores for CB-S, CT-S and CP-S. That's present the effect of spirulina in appearance also. The most preferable color for the panelists was recorded for the same appearance preferable formulas. While, lowest score was recorded for $\mathrm{CP}+\mathrm{S}, \mathrm{CT}+\mathrm{S}$ and $\mathrm{CB}+\mathrm{S}$. Results for taste, as the most important organoleptic property showed that $\mathrm{CB}-\mathrm{S}$ and $\mathrm{CT}+\mathrm{S}$ were the best favored significantly. Odor fascinates the consumer and is able to increase his appetite. The highest score was recorded for $\mathrm{CB}-\mathrm{S}$ that flowed by CT-S formulas. The cooking method affected the texture of those innovative diets, where the negligible difference was found either spirulina or without spirulina integration. Oiliness reflects the oil retaining after cooking and panelists were asked to give higher score for lower oil content after pressing the bars between their fingers. The lowest retentive oil level had been noted for $\mathrm{CB}+\mathrm{S}$ while the highest retaining oil level bad been recorded for CP-S, significantly. Moreover, the overall acceptability scores indicated that the different diets could be arranged as $\mathrm{CB}-\mathrm{S}>\mathrm{CT}-\mathrm{S}>\mathrm{CP}-\mathrm{S}>\mathrm{CT}+\mathrm{S}>\mathrm{CP}+\mathrm{S}$ $>\mathrm{CB}+\mathrm{S}$. These results are more or less agreement with (Heenan et al., 2004; Barakat, 2013; Barakat, 2014; Barakat and Rohn, 2014).

Table 9. Organoleptic properties of innovative read-to-eat chickpea-based ovo-vegetarian diets incorporating different vegetables and supplemented with spirulina

\begin{tabular}{|c|c|c|c|c|c|c|c|}
\hline \multirow[b]{2}{*}{ Recipes $^{¥}$} & \multicolumn{7}{|c|}{ Organoleptic properties } \\
\hline & Appearance & Color & Taste & Odor & Texture & Oiliness & $\begin{array}{c}\text { Overall } \\
\text { acceptability }\end{array}$ \\
\hline \multirow{2}{*}{ CP-S } & 5.46 & 5.46 & 4.23 & 4.58 & 5.54 & 5.31 & 4.62 \\
\hline & $\pm 1.05^{\mathrm{c}}$ & $\pm 1.39^{\mathrm{b}}$ & $\pm 1.42^{\mathrm{ab}}$ & $\pm 1.35^{\mathrm{a}}$ & $\pm 0.88^{\mathrm{b}}$ & $\pm 0.95^{\mathrm{ab}}$ & $\pm 1.19^{\mathrm{ab}}$ \\
\hline \multirow{2}{*}{$\mathrm{CP}+\mathrm{S}$} & 2.92 & 2.38 & 3.19 & 3.69 & 4.92 & 4.77 & 3.69 \\
\hline & $\pm 1.75^{\mathrm{a}}$ & $\pm 1.80^{\mathrm{a}}$ & $\pm 1.97^{\mathrm{a}}$ & $\pm 1.97^{\mathrm{a}}$ & $\pm 1.19^{\mathrm{a}}$ & $\pm 1.09^{\mathrm{a}}$ & $\pm 1.32^{\mathrm{a}}$ \\
\hline \multirow{2}{*}{ CT-S } & 5.35 & 5.50 & 3.62 & 4.65 & 5.31 & 5.00 & 4.85 \\
\hline & $\pm 0.90^{\mathrm{c}}$ & $\pm 0.91^{\mathrm{a}}$ & $\pm 1.71^{\mathrm{a}}$ & $\pm 1.38^{\mathrm{a}}$ & $\pm 0.95^{\mathrm{b}}$ & $\pm 1.00^{\mathrm{ab}}$ & $\pm 1.07^{\mathrm{ab}}$ \\
\hline \multirow{2}{*}{$\mathrm{CT}+\mathrm{S}$} & 3.08 & 2.46 & 4.46 & 4.27 & 5.08 & 4.54 & 4.23 \\
\hline & $\pm 1.61^{\mathrm{ab}}$ & $\pm 1.71^{\mathrm{a}}$ & $\pm 1.51^{\mathrm{ab}}$ & $\pm 1.79^{\mathrm{a}}$ & $\pm 1.12^{\mathrm{ab}}$ & $\pm 1.13^{\mathrm{a}}$ & $\pm 1.42^{\mathrm{ab}}$ \\
\hline \multirow{2}{*}{$\mathrm{CB}-\mathrm{S}$} & 5.58 & 5.50 & 5.62 & 5.00 & 5.38 & 5.23 & 5.46 \\
\hline & $\pm 1.08^{\mathrm{c}}$ & $\pm 1.08^{\mathrm{b}}$ & $\pm 0.96^{\mathrm{c}}$ & $\pm 1.29^{\mathrm{b}}$ & $\pm 0.77^{\mathrm{b}}$ & $\pm 1.01^{\mathrm{ab}}$ & $\pm 0.97^{\mathrm{c}}$ \\
\hline \multirow{2}{*}{$\mathrm{CB}+\mathrm{S}$} & 3.27 & 2.46 & 3.81 & 3.92 & 4.62 & 4.23 & 3.85 \\
\hline & $\pm 1.27^{\mathrm{b}}$ & $\pm 1.39^{\mathrm{a}}$ & $\pm 1.84^{\mathrm{a}}$ & $\pm 1.85^{\mathrm{a}}$ & $\pm 1.61^{\mathrm{a}}$ & $\pm 1.42^{\mathrm{a}}$ & $\pm 1.72^{\mathrm{a}}$ \\
\hline
\end{tabular}

$¥$ : see materials and methods, table 1 ,

a,b,c,....: Means with the same letter in the same column are not significantly different $(p>0.05)$. 


\section{Conclusion}

Reduced risk of many diseases in health-conscious are strongley associated with consuming vegetarian and functional diets. Accordingly, moderation, variety and appealing in individual diets is recommended. The current study concluded the potential applicability of different innovative OVDs incorporating different vegetables and supplemented with spirulina. Obtained results could provide sufficient information about macro- and micronutrients, phytochemicals content and their antioxidant activity, amino acids as well as sensory attractiveness of prepared OVDs. Highly consumer acceptability could be an encourage motive for large scale applications. However, studies about formulating different functional diets with spirulina could be an innovative issue to establish novel functional vegetarian diets for vegetarians. The present investiagtion could also provide a valuable impact of cooking method to optimize the cooking procedure for designing novel functional foods for spicific group.

\section{References}

A.O.A.C. (2000). Official methods of analysis of the aoac, Association of Official Analytical Chemists. USA.

A.O.A.C. (2012). Official methods of analysis of the aoac international no. 994.12, Official Journal of the European communities 19.9.98. USA.

Al-Duais, M ؛.Hohbein, J.; Werner, S.; Böhm, V. and Jetschke, G. (2009). Contents of vitamin c, carotenoids, tocopherols, and tocotrienols in the subtropical plant species cyphostemma digitatum as affected by processing. Journal of Agricultural and Food Chemistry 57(2): 5420-5427.

Barakat, H. (2013). Characterization and evaluation of kohlrabi (Brassica oleracea 1. Gongylodes) and kohlrabibased ovo-vegetarian diets as new food recipes. Egyptian Journal of Food Science 41: 35-61.

Barakat, H. (2014). Fate of nutritional and bioactive compounds of innovative chickpeas-based vegan diets incorporating different vegetables. Journal of Nutrition \& Food Sciences 2014.

Barakat, H. and Rohn, S. (2014). Effect of different cooking methods on bioactive compounds in vegetarian, broccoli-based bars. Journal of Functional Foods 11: 407-416.

Batista, A. P.; Nunes, M.; Raymundo, A.; Gouveia, L.; Sousa, I.; Cordobés, F.; Guerrero, A. and Franco, J. (2011). Microalgae biomass interaction in biopolymer gelled systems. Food hydrocolloids 25(4): 817-825.
Borah, S.; Baruah, A.; Das, A. and Borah, J. (2009). Determination of mineral content in commonly consumed leafy vegetables. Food Analytical Methods 2(3): 226-230.

Buchner, N.; Krumbein, A.; Rohn, S. and Kroh, L. W. (2006). Effect of thermal processing on the flavonols rutin and quercetin. Rapid Communications in Mass Spectrometry 20(21): 3229-3235.

Chiplonkar, S. A.; Tarwadi, K. V.; Kavedia, R. B.; Mengale, S. S.; Paknikar, K. M. and Agte, V. V. (1999). Fortification of vegetarian diets for increasing bioavailable iron density using green leafy vegetables. Food Research International 32(3): 169-174.

Craig, W. J. and Mangels, A. R. (2009). Position of the american dietetic association: Vegetarian diets. Journal of the American Dietetic Association 109(7): 266-282.

Deng, G.; Lin, X.; Xu, X.; Gao, L.; Xie, J. and Li, H. (2013). Antioxidant capacities and total phenolic contents of 56 vegetables. Journal of Functional Foods 5(1): 260-266.

Doria, E.; Campion, B.; Sparvoli, F.; Tava, A. and Nielsen, E. (2012). Anti-nutrient components and metabolites with health implications in seeds of 10 common bean (Phaseolus vulgaris L. and Phaseolus lunatus 1.) landraces cultivated in southern italy. Journal of Food Composition and Analysis 26(1-2): 72-80.

DRI (2002). Dietary reference intakes for energy, carbohydrate, fiber, fat, fatty acids, cholesterol, protein, and amino acids. Food and Nutrition Board, Institute of Medicine, The national academic press, Washington, D.C.

Fradique, M.; Batista, A. P ؛.Nunes, M. C.; Gouveia, L.; Bandarra, N. M. and Raymundo, A. (2010). Incorporation of chlorella vulgaris and spirulina maxima biomass in pasta products. Part 1: Preparation and evaluation. Journal of the Science of Food and Agriculture 90(10): 16561664.

Francisco, M.; Velasco, P.; Moreno, D. A.; GarcíaViguera, C. and Cartea, M. E. (2010). Cooking methods of brassica rapa affect the preservation of glucosinolates, phenolics and vitamin c. Food Research International 43(5): 1455-1463.

Fraser, G. E. (2009. Vegetarian diets: What do we know of their effects on common chronic diseases? The American Journal of Clinical Nutrition 89(5): 1607S-1612S.

Gebhardt, S. E. and Thomas, R. G. (2002). Nutritive value of foods. U.S. Department of agriculture, agricultural research service, home and garden bulletin no. 72, nutrient data laboratory, beltsville, maryland, U.S. Department of Agriculture, Agricultural Research Service, Nutrient Data Laboratory, Beltsville, Maryland. 
Gertz, C.; Klostermann, S. and Kochhar, S. P. (2000). Testing and comparing oxidative stability of vegetable oils and fats at frying temperature. European Journal of Lipid Science and Technology 102(8-9): 543-551.

Gliszczynska-Swiglo, A.; Ciska, E.; PawlakLemanska, K.; Chmielewski, J.; Borkowski ‘T. and Tyrakowska, B. (2006). Changes in the content of health-promoting compounds and antioxidant activity of broccoli after domestic processing. Food Additives and Contamination 23(11): 1088-1098.

Gorinstein, S.; Park, Y.; Heo, B.; Namiesnik, J.; Leontowicz, H.; Leontowicz, M.; Ham, K.; Cho, J. and Kang, S. (2009). A comparative study of phenolic compounds and antioxidant and antiproliferative activities in frequently consumed raw vegetables. European Food Research and Technology 228(6): 903-911.

Gouveia, L.; Coutinho, C.; Mendonça, E.; Batista, A.; Sousa, I.; Bandarra, N. and Raymundo, A. (2008). Sweet biscuits with isochrysis galbana microalga biomass as a functional ingredient. Journal of the Science of Food and Agriculture 88: 891-896.

Heenan, C. $\mathbf{N}$ ؛.Adams, M. C.; Hosken, R. W. and Fleet, G. H. (2004). Survival and sensory acceptability of probiotic microorganisms in a nonfermented frozen vegetarian dessert. $L W T$ Food Science and Technology 37(4): 461-466.

Houghton, C. A.; Fassett, R. G. and Coombes, J. S. (2013). Sulforaphane: Translational research from laboratory bench to clinic. Nutrition Reviews 71(11): 709-726.

Hunt, J. R. (2003). Bioavailability of iron, zinc, and other trace minerals from vegetarian diets. The American Journal of Clinical Nutrition 78(3): 633S-639S.

Ismail, A.; Marjan, Z. M. and Foong, C. W. (2004). Total antioxidant activity and phenolic content in selected vegetables. Food Chemistry 87(4): 581586.

Jacobo-Valenzuela, N.; Maróstica-Junior, M.; Zazueta-Morales, J. and Gallegos-Infante, J. (2011). Physicochemical, technological properties, and health-benefits of cucurbita moschata duchense vs. Cehualca: A review. Food Research International 44(9): 2587-2593.

Jakszyn, P.; Gonzalez, L.; Lujan-Barroso, M. M.; Ros, H. B.; Bueno-de-Mesquita, N.; Roswall, A. M.; Tjonneland, F. L.; Buchner, L.; Egevad, K.; Overvad, O.; Raaschou-Nielsen, F.; Clavel-Chapelon, M.; Boutron-Ruault, $M$. S.; Touillaud, J.; Chang-Claude, N. E.; Allen, L. A.; Kiemeney, T. J.; Key, R.; Kaaks, H.; Boeing, S ؛.Weikert, A.; Trichopoulou, E.; Oikonomou, D.; Zylis, D.; Palli, F.; Berrino, P.; Vineis, R.; Tumino, A.; Mattiello, P. H. M.; Peeters, C. L.; Parr, I. T.; Gram, G.; Skeie, M.; Sanchez, N.; Larranaga, E.; Ardanaz, C.;
Navarro, L.; Rodriguez, D.; Ulmert, $\mathrm{R}$ !. Ehrnstrom, G.; Hallmans, B.; Ljungberg, A. W.; Roddam, S. A.; Bingham, K.; Khaw, N.; Slimani, P. A.; Boffetta, M.; Jenab, T.; Mouw, D. S.; Michaud, E. and Riboli, E. (2011). Red meat, dietary nitrosamines, and heme iron and risk of bladder cancer in the european prospective investigation into cancer and nutrition (epic). Cancer Epidemiology, Biomarkers \& Prevention 20(3): 555-559.

Jongen, W. M. and Meerdink, G. (2001). Pea proteins based food products as meat replacers: The profetas concept. Nahrung 45(6): 402-404.

Krumbein, A.; Schonhof, I. and Brückner, B. (2006). Flavour and health-promoting compounds in broccoli and cauliflower-an inconsistency? Developments in food science. Wender, L. P. B. and Mikael Agerlin, P., Elsevier. 43: $249-252$.

Kumaran, A .and Joel Karunakaran, R. (2007). In vitro antioxidant activities of methanol extracts of five phyllanthus species from india. $L W T$ - Food Science and Technology 40(2): 344-352.

Lamy, E.; Scholtes, C.; Herz, V. and MerschSundermann, V. (2011). Pharmacokinetics and pharmacodynamics of isothiocyanates. Drug Metabolism Reviews 43(3): 387-407.

Lightowler, H. J. and Davies, G. J. (2000). Micronutrient intakes in a group of uk vegans and the contribution of self-selected dietary supplements. Journal of the Royal Society for the Promotion of Health 120(2): 117-124.

Limón, R. I.; Peñas, E.; Martínez-Villaluenga, C. and Frias, J. (2014). Role of elicitation on the health-promoting properties of kidney bean sprouts. LWT - Food Science and Technology 56(2): 328-334.

Lu, J.; Zhao, H.; Chen, J.; Fan, W.; Dong, J.; Kong, W.; Sun, J.; Cao, Y. and Cai, G. (2007). Evolution of phenolic compounds and antioxidant activity during malting. Journal of Agricultural and Food Chemistry 55(26): 1099411001.

Mangels, A. R. and Messina, V. (2001). Considerations in planning vegan diets: Infants. Journal of the American Dietetic Association 101(6): 670-677.

McEvoy, C. T.; Temple-Woodside, J. V. and Woodside, J. V. (2012). Vegetarian diets, lowmeat diets and health: A review. Public Health Nutrition 15(12): 2287-2294.

Merrill, A. L. and Watt, B. K. (1973). Energy value of foods: Basis and derivation. Agriculture handbook no. 74. Washington, dc, ars united states department of agriculture.

Messina, M. J. (1991). Legumes and soybeans : Overview of their nutritional profiles and health effects. The American Journal of Clinical Nutrition 70(3 Suppl): 439S-450S. 
Messina, M. J. (1999). Legumes and soybeans: Overview of their nutritional profiles and health effects. The American Journal of Clinical Nutrition 70(3 Suppl): 439S-450S.

Messina, V. and Mangels, A. R. (2001). Considerations in planning vegan diets: Children. Journal of the American Dietetic Association 101(6): 661-669.

Micha, R.; Wallace, D. and Mozaffarian, D. (2010). Red and processed meat consumption and risk of incident coronary heart disease, stroke, and diabetes mellitus: A systematic review and metaanalysis. Circulation 121(21): 2271-2283.

Mitchell, D. C.; Lawrence, F. R.; Hartman, T. J. and Curran, J. M. (2009). Consumption of dry beans, peas, and lentils could improve diet quality in the us population. Journal of the American Dietetic Association 109(5): 909-913.

Mohdaly, A. A. A.; Hassanien, M. F. R.; Mahmoud, A.; Sarhan, M. A. and Smetanska, I. (2012). Phenolics extracted from potato, sugar beet, and sesame processing by-products. International Journal of Food Properties 16(5): 1148-1168.

Nilsson, J.; Stegmark, R. and Åkesson, B. (2004). Total antioxidant capacity in different pea (Pisum sativum) varieties after blanching and freezing. Food Chemistry 86(4): 501-507.

Pulz, O. and Gross, W. (2004). Valuable products from biotechnology of microalgae. Applied microbiology and biotechnology 65(6): 635-648.

Raymundo, A.; Gouveia, L.; Batista, A.; Empis, J. and Sousa, I. (2005). Fat mimetic capacity of chlorella vulgaris biomass in oil-in-water food emulsions stabilized by pea protein. Food Research International 38(8): 961-965.

Richmond, A. (2008). Handbook of microalgal culture: Biotechnology and applied phycology, John Wiley \& Sons.

Sacks, F. M. and Kass, E. H. (1988). Low blood pressure in vegetarians: Effects of specific foods and nutrients. The American Journal of Clinical Nutrition 48(3 Suppl): 795-800.

Segev, A. (2011). Total phenolic content and antioxidant activity of chickpea (Cicer arietinum L.) as affected by soaking and cooking conditions. Food and Nutrition Sciences 02(07): 724-730.

Sikora, E.; Cieslik, E.; Leszczynska, T.; FilipiakFlorkiewicz, A. and Pisulewski, P. M. (2008). The antioxidant activity of selected cruciferous vegetables subjected to aquathermal processing. Food Chemistry 107(1): 55-59.
Steel, R.; Torrie, J. and Dickey, D. (1997). Principles and procedures of statistics: A

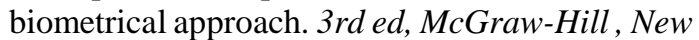
York, $N Y$.

Świątecka, D.; Świątecki, A.; Kostyra, H.; Marciniak-Darmochwal, K. and Kostyra, E. (2010). The impact of pea protein hydrolysates on bacterial physiological activity-an in vitro study. International Journal of Food Microbiology 140(2-3): 263-270.

Tang, G. (2010). Chapter 25 - spinach and carrots: Vitamin a and health. Bioactive foods in promoting health. Watson, R. R. and Preedy, V. R. San Diego, Academic Press: 381-392.

Turkmen, N.; Sari, F. and Velioglu, Y. S. (2005). The effect of cooking methods on total phenolics and antioxidant activity of selected green vegetables. Food Chemistry 93(4): 713-718.

Turner-McGrievy, G. (2010). Nutrient adequacy of vegetarian diets. Journal of the American Dietetic Association 110(10): 1450.

Verkerk, R.; Schreiner, M.; Krumbein, A ؛.Ciska, E.; Holst, B.; Rowland, I.; De Schrijver, R.; Hansen, M.; Gerhäuser, C.; Mithen, R. and Dekker, M. (2009). Glucosinolates in brassica vegetables: The influence of the food supply chain on intake, bioavailability and human health. Molecular Nutrition \& Food Research 53(S2): S219-S219.

Volden, J.; Borge, G. I. A.; Bengtsson, G. B.; Hansen, M.; Thygesen, I. E. and Wicklund, T. (2008). Effect of thermal treatment on glucosinolates and antioxidant-related parameters in red cabbage (Brassica oleracea L. ssp. Capitata f. Rubra). Food Chemistry 109(3): 595605.

Wilson, C. D.; Pace, E.; Bromfield, G.; Jones, J. Y. and Lu, J. Y. (1998). Consumer acceptance of vegetarian sweet potato products intended for space missions. Life Support Biosph Sci 5(3): 339-345.

Yuan, G. F.; Sun, J.; Yuan, Q. and Wang, Q. M. (2009). Effects of different cooking methods on health-promoting compounds of broccoli. Journal of Zhejiang University-SCIENCE B 10(8)(1862-1783 (Electronic)): 580-588.

Zhang, D. and Hamauzu, Y. (2004). Phenolics, ascorbic acid, carotenoids and antioxidant activity of broccoli and their changes during conventional and microwave cooking. Food Chemistry 88(4): 503-509. 


\title{
الخصائص التغذوية والمركبات النشطة حيويا لمختلف وجبات الاوفو - النباتية المدعمة بالاسبيرولينا
}

\author{
جلال عبد القتاح ابراهيم غزال

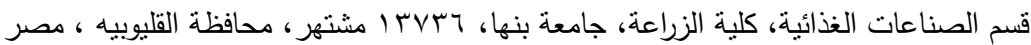 \\ الملخص العريى
}

أوصت البحوث المبتكرة خلال السنوات القلبلة الماضية في مجال تغذية الإنسان مدى أهمية مساهمة النظام الغذائي النباتي وظيفته فى تحسين صحة الإنسان وتقليل خطر التعرض للأمراض. في الدراسة الحالية، تم إعداد ثلاثة وجبات نباتية مبتكرة جاهزة للاستخدام (RTU) و ثلاثة وجبات نباتية مبتكرة جاهزة للأكل (RTE) مكونة اساساً من الحمص كمكون اساسى مع دمج أنواع مختلفة من الخضروات مثل (البازلاء، القلقاس

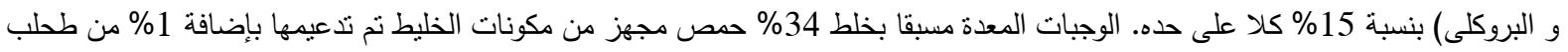
الاسبيرولينا المجف حيث تم تصنيع وجبات نباتية مدعمة بالاسبيرولينا وإخرى غير مدعة ككنترول لنفس نوع الخضار المستخدم ليكونوا ستة وجبات جاهزة للأكل منها ثلاثة مدعمين بالاسبيرولينا وثلاثة غير مدعمين بالاسبيرولينا. تم تحميير الوجبات فى الزيت لتجهيز الوجبات النباتية الجاهزة للاكل. تمت دراسة الخصائص التغذوية والمركبات النشطة حيوياً للوجبات النباتية المعدة. تم تقدير التركيب الكيميائي، محتوى المعادن، المركبات النشطة حيوياً والنشاط المضاد للأكسدة وكذلك محتوى الأحماض الأمينية فى الوجبات النباتبة قبل وبعد الطهى. نم أيضا تحكيم الوجبات المدعمة

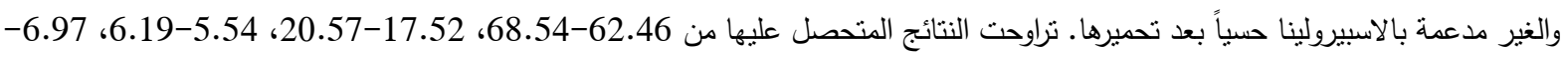
8.92، 5.09-6.65 و 61.50-83.84\% لكل من محتوى الرطوبة، والبروتين الخام، الدهون، الرماد، الألباف والكربوهيدرات المتاحة في الوجبات النباتية الجاهزة للإستخدام، على التوالي. أظهرت النتائج وجود فروق معنوية في التركيب الكيميائي والسعرات الحرارية بين كل من الوجبات النباتية

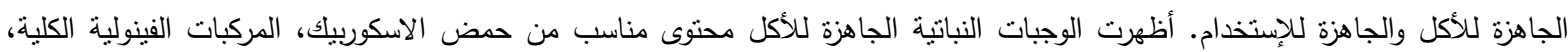
الفلافونويدات و الفلافونولات معتمداً أساساً على مكوناتها كما إمتلكت نشاطاً عالياً كمضاداً للأكسدة. فى حين أن، عملية الطهى بالتحميير خفضت الته محتوى كلا من حمض الأسكوربيك، الفلافونويدات الفلافونولات بشكل ملحوظ معنوياً. علاوة على ذلك، فإن إضافة الاسبيرولينا أدى إلى زيادة محتوى المعادن، المواد الكيميائية النباتية والأحماض الأمينية فى الوجبات النباتية الجاهزة للأكل. القبول الحسى العالى الذى تم تسجيلة للوجبات

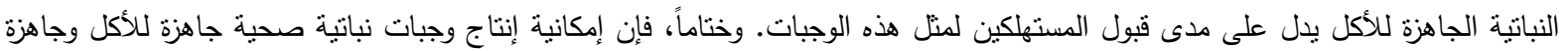
للإستخدام بدمج بعض الخضروات مع تدعيمهاً بالاسبيرولينا يمكن أن نوفر نهجاً واعداً لتحسين صحة الإنسان ونمطه الغذائي كما يعد من الأغذية الوظيفية. 